\title{
ADENOIDECTOMY BY DIFFERENT TECHNIQUES (COMPARATIVE STUDY)
}

\author{
By
Atef Abdullah El-Maraghy, Hatem Salah El-Din El-Habashy and Hazem Ahmed Mohammed Ahmed* \\ Otorhinolaryngology Department, Faculty of Medicine, Al-Azhar University \\ *Corresponding author: Hazem Ahmed Mohammed Ahmed, Mobil: 01099559484 \\ E-mail:esawi87@yahoo.com
}

\begin{abstract}
Background: Adenoidectomy is one of the most common pediatric ambulatory procedure in the world, multiple techniques are present for adenoidectomy with relative advantages and dis advantages of each technique.

Objectives: Providing a comparative study of adenoidectomy by electrocautary with suction diathermy, conventional and microdebrider techniques.

Patients and Methods: Randomized prospective study included 60 child patients with age ranged from (3$12 \mathrm{y}$ ) of both genders (28 males and 32 females), all suffering from hypertrophied adenoid tissue, presented clinically with mouth breathing, snoring, partial nasal obstruction and/or discharge and evidenced radiologically with plain X-ray film lateral view to the nasopharynx. All cases presented to Al-Azhar University Hospitals (Al-Hussin \& Sayed galal) during the period from July 2018 to December 2018.

Results: The mean blood loss in suction diathermy technique was $(5.56 \mathrm{ml})$ while in conventional and microdebrider techniques were $43.45 \mathrm{ml}$ and $31.90 \mathrm{ml}$ respectively and this found to be of highly statistical significance. Also in complete of removal of adenoid tissue there were significant statistical difference between conventional and microdebrider ( $p$-value:0.02) also between conventional technique and suction diathermy technique ( $\mathrm{p}$-value $<0.03$ ) but as regard operative time there was highly significant statistical difference between conventional and microdebrider ( $\mathrm{p}$-value $<0.001$ ).

Conclusion: The suction diathermy adenoidectomy is the technique of choice in lowering intraoperative blood loss compared to other tow techniques, also sharing microdebrider technique in visibility of the surgical field and completeness of resection, when the cost and availability are affordable it will be the gold standard technique for adenoidectomy, the conventional technique have a disadvantages of bleeding, traumatic and incomplete of resection but still cheapest, simplest and most available one.
\end{abstract}

Key words: Adenoidectomy, Myringotomy, Adenotonsillectomy.

\section{INTRODUCTION}

Adenoidectomy is the third most common pediatric ambulatory procedure in the United States, following myringotomy with tube placement and adenotonsillectomy (Cullen et al., 2009).
Common indications for adenoidectomy include obstructive sleep apnea, nasal obstruction, chronic otitis media, adenoid hypertrophy, and chronic adenoiditis. Surgery often is performed 
between the ages of 2 to 5 years old (Gerhardsson et al., 2016).

Several different surgical techniques have been described for adenoidectomy. In the last decades, a movement from cold techniques to electrosurgical methods such as electrocautery has taken place (Wilson et al., 2009).

Studies have focused on comparison of curettage to electrocautery, suggesting the latter is superior in terms of blood loss, operative time, and precision (Hajr et al., 2011).

The adenoidectomy was developed in the pre-endoscopic era. At that time, curettes were used to "blindly" remove the hyperplastic tissue. That is, the surgical field and the tissue to be removed were not directly visualized, but only "palpated with the tip of the fingers" (Ruben, 2017).

With the advent of sinonasal endoscopy, it has become possible to remove adenoid tissue under direct visualization, with greater control of the procedure and the tissue to be removed (Kurtaran et al., 2011).

A study on preferred tonsillectomy and adenoidectomy methods among the members of the American Society of Pediatric Otolaryngology (ASPO) suggested that electrocautery adenoidectomy was the most common method used for adenoidectomy (Yaman et al., 2015).

The aim of this work was to provide a comparative study of adenoidectomy by electrocutary with suction diathermy, conventional and microdebrider techniques.

\section{PATIENTS AND METHODS}

This was a randomized prospective study conducted in the Department of Otorhinolaryngology, Al-Azhar University Hospitals, Cairo, Egypt during the period from July 2018 to December 2018. The study included a total of 60 cases suffering from hypertrophied adenoid, and was planned for adenoidectomy. The aim and nature of the study was explained for parents of children before inclusion. An informed written concent was obtained before enrollment.

The included patients were divided randomly into 3 equal groups as follows:

Group I: included patients underwent adenoidectomy through conventional technique.

Group II: included patients underwent adenoidectomy through microdebrider technique.

Group III: included patients that doing adenoidectomy through suction diathermy technique.

Patients were excluded if their age under 3 or above 12 years to limits our study with patients in childhood period as this age group represent the majority of our target cases, also we excluded patients with recurrent adenoids to avoid the effects of previous surgery on the nasopharynx, children with congenital diseases such as cystic fibrosis or cleft palate and child with bleeding disorders also excluded from the study. 
All patients were subjected to full history taken, full ENT examinations, preoperative routine laboratory investigations was done .Also preoperative X-ray nasopharynx lateral view with soft tissue radiation dose with open mouth and extended neck. The adenoidal hypertrophy was compared with the rest of the air way and accordingly the degree of obstruction was categorized into 4 grades:

Grade $0=0-25 \%$ obstruction,

Grade $1=25-50 \%$ obstructions,

Grade $2=50-75 \%$ obstruction, and

Grade $3=75-100 \%$ obstructions.

Grades 2 and 3 were considered obstructive adenoid and needed surgical intervention.

\section{Surgical Procedure:}

All patients were operated under general anesthesia via cuffed endotracheal through oral intubation.

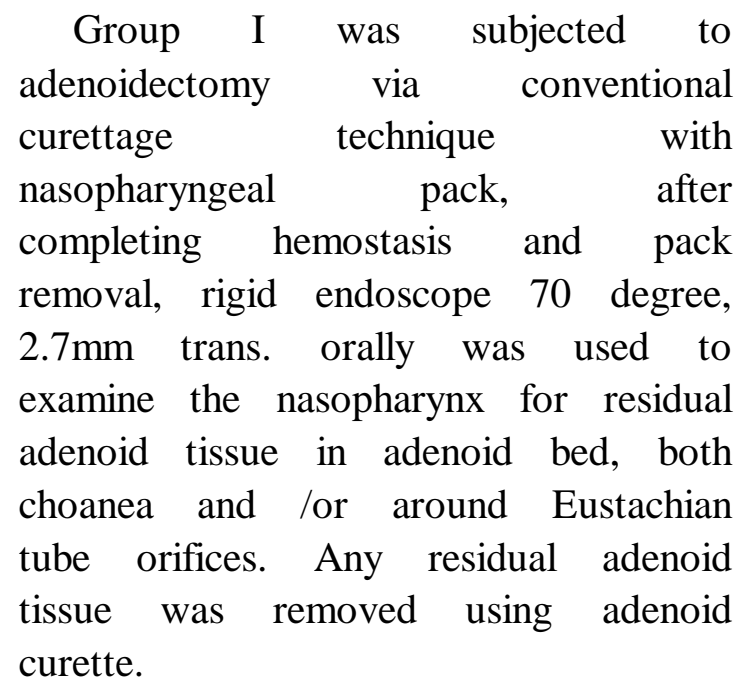

Group II in which adenoid was resected by using powered microdebrider XPS® $3000 \quad$ (Storz- unidrive S III Eco Germany 407014 20) were used to resect adenoidal tissue trans orally after retraction of soft palate by 2 rubber catheter through the nostrils that comes out from the mouth and clamped under tension to allow access to nasopharynx and directly visualized the adenoidal tissue and adjacent structure in nasopharynx.Under an endoscopic view of $4 \mathrm{~mm} 70$ degree, the tip of microdebrider $\left(\right.$ RAdenoid $^{\circledR}$, pediatric blade $4 \mathrm{~mm}$; Storz.) was inserted into the nasopharyngeal hollow and by using speed of 1500 rpm in oscillating mode. The hand piece was connected to a continuous suction and irrigation system and the adenoidal tissue sucked into the cutting window was resected by rotating blade. The resection were done by side to side sweeping motion starting from choanae and proceeded posteriorly and inferiorly until all adenoidal tissue was resected, hemostasis was done by using nasopharyngeal pack with gauze.

Group III in which adenoidectomy was done via suction diathermy technique in which the soft palate was retracted by two suction catheter as discussed previously and directly visualized the adenoidal tissue and adjacent structure in nasopharynx by using 70 degree angled endoscope placed in the oropharynx. Diathermic ablation of the adenoid is accomplished by using a disposable , malleable size 10 or 12 hand switching suction coagulator (valley lab) using a current (38w) adenoidal tissue was diathermy ablated simultaneously with suction starting 
at the most superior part of adenoidal tissue and the procedure was completed when the posterior choanae was clearly visible with smooth contour of nasopharynx .

The time of operation was recorded starting with introducing the instrument into the nasopharynx. Intraoperative and immediate postoperative complications such as hemorrhage, injury to palate, torus or posterior part of septum were recorded for comparison between study groups. Amount of blood loss during operation were collected and estimated in every group for comparison.

Postoperative care and follow up: After complete recovery, all patients were received antibiotics for one week postoperatively with analgesic and local nasal decongestant. Patients were followed up after 1, 2 weeks and then after 2 months after operation for check any recurrence.

\section{Statistical analysis:}

Statistical analysis of the data was performing by SPSS-22 software package (Illinois, Chicago, USA). Presented in the form of frequency and percent. Quantitative data were expressed in the form of mean $\pm \mathrm{SD}$, comparison between groups were performed by chi-square ( X2) test for categorized data and by independent sample, T-test when comparing two groups of operations. While One-way ANOVA for remaining comparison (more than two groups of operations) followed by post-hoc test. Probability level (p-value) was assumed significant if $\mathrm{P}$-value was

\section{RESULTS}

The present study included a total number of 60 cases (34 males and 26 females) presented with adenoid hypertrophy with age ranged from (3- 12 years). The patients were divided randomly in to 3 groups. The results demonstrated that there were no significant statistical differences between the groups as regard age and sex distribution (Table 2) .The results of comparison of the study groups as regard operative time (min) showed that there were highly significant statistical differences between conventional and microdebrider techniques. Also, there were significant statistical differences between microdebrider and suction diathermy techniques, while there were no significant statistical differences between conventional and suction diathermy techniques (Table 2).

The results showed highly significant Statistical differences between suction diathermy and the other 2 techniques while there was significant statistical differences between microdebrider and conventional techniques. The mean blood loss was the lowest in suction diathermy technique $(5.65 \pm 1.59)$, while it was found the highest in conventional technique (43.45 \pm 15.27$)$ (Table 2).

Regarding the results of comparison between the 3 groups as regard complete of removal of the adenoid, there was significant Statistical differences between conventional technique when compared 


\section{ADENOIDECTOMY BY DIFFERENT TECHNIQUES (COMPARATIVE... 703}

with both microdebrider and suction diathermy techniques (Table 2).

Regarding the intraoperative complications of the 3 groups conventional technique found to be high percentage of intraoperative complications when compared to other techniques but this difference found to be non-significant.

Table (1): Comparison between different groups (Mean \pm SD)

\begin{tabular}{|c|c|c|c|c|c|}
\hline \multicolumn{2}{|c|}{ Parameters Groups } & $\begin{array}{c}\text { Conventional } \\
\text { Technique }\end{array}$ & $\begin{array}{l}\text { Microdebrider } \\
\text { Technique }\end{array}$ & $\begin{array}{l}\text { Suction } \\
\text { Diathermy } \\
\text { Technique }\end{array}$ & P-Value \\
\hline \multirow{2}{*}{ Age (years) } & Mean & 5.85 & 4.7 & 5.9 & \multirow{2}{*}{0.11} \\
\hline & Std Dev & 2.47 & 1.30 & 2.07 & \\
\hline \multirow{2}{*}{ Sex } & Female & 11 & 13 & 8 & \multirow{2}{*}{0.13} \\
\hline & Male & 9 & 7 & 12 & \\
\hline \multirow{2}{*}{$\begin{array}{l}\text { Operative Time } \\
\text { (min) }\end{array}$} & Mean & 10 & 12.8 & 11.35 & \multirow{2}{*}{0.002} \\
\hline & Std Dev & 1.16 & 2.44 & 2.20 & \\
\hline \multirow{2}{*}{ Bleeding Loss (ml) } & Mean & 43.45 & 31.90 & 5.56 & \multirow{2}{*}{$<0.001$} \\
\hline & Std Dev & 15.27 & 5.75 & 1.59 & \\
\hline \multirow{3}{*}{$\begin{array}{l}\text { Complete } \\
\text { Removal }\end{array}$} & Excellent & 5 & 20 & 20 & \multirow{3}{*}{0.041} \\
\hline & \begin{tabular}{|l|} 
Good \\
\end{tabular} & 5 & 0 & 0 & \\
\hline & Fair & 10 & 0 & 0 & \\
\hline \multirow{3}{*}{$\begin{array}{l}\text { Intraoperative } \\
\text { Complications }\end{array}$} & \begin{tabular}{|l|} 
No I.O. \\
Complication \\
\end{tabular} & 15 & 20 & 20 & \multirow{3}{*}{0.047} \\
\hline & ML. on vomer & 2 & 0 & 0 & \\
\hline & \begin{tabular}{|l|} 
ML. on the \\
tours
\end{tabular} & 3 & 0 & 0 & \\
\hline \multirow{2}{*}{$\begin{array}{l}\text { Period of hospital } \\
\text { stay (hours) }\end{array}$} & Mean & 6.75 & 6.85 & 6.80 & \multirow[t]{2}{*}{0.93} \\
\hline & Std Dev & .851 & .875 & .834 & \\
\hline
\end{tabular}


ATEF ABDULLAH EL-MARAGHY et al.,

Table (2): $P$ value in different groups

\begin{tabular}{|c|c|c|c|}
\hline Parameters & \multicolumn{2}{|c|}{ Groups } & p-value \\
\hline \multirow{3}{*}{ Age (years) } & Conventional Technique & Microdebrider Technique & 0.076 \\
\hline & Microdebrider Technique & Suction Diathermy Technique & 0.064 \\
\hline & Suction Diathermy Technique & Conventional Technique & 0.938 \\
\hline \multirow{3}{*}{$\begin{array}{c}\text { Operative } \\
\text { Time (min) }\end{array}$} & Conventional Technique & Microdebrider Technique & $<0.001$ \\
\hline & Microdebrider Technique & Suction Diathermy Technique & 0.019 \\
\hline & Suction Diathermy Technique & Conventional Technique & 0.080 \\
\hline \multirow{3}{*}{ Bleeding $(\mathrm{ml})$} & Conventional Technique & Microdebrider Technique & 0.003 \\
\hline & Microdebrider Technique & Suction Diathermy Technique & $<0.001$ \\
\hline & Suction Diathermy Technique & Conventional Technique & $<0.001$ \\
\hline \multirow{3}{*}{$\begin{array}{c}\text { Complete of } \\
\text { Removal }\end{array}$} & Conventional Technique & Microdebrider Technique & 0.02 \\
\hline & Microdebrider Technique & Suction Diathermy Technique & 0.070 \\
\hline & Suction Diathermy Technique & Conventional Technique & 0.03 \\
\hline
\end{tabular}

\section{DISCUSSION}

Adenoidectomy has been the standard treatment protocol of adenoid hypertrophy for years (Lapińska and Zawadzka-głos, 2016).

Conventional curettage adenoidectomy guided by digital palpation is a simple and quick procedure that has already been in use for a long time. This technique carries the risk of blind working in operation area. The complications of conventional curettage adenoidectomy are bleeding, nasopharyngeal stenosis, and eustachian tube stenosis and leave behind obstructing tissue (Somani et al., 2010).

Many guided techniques were described to reduce recurrence rates $b$. The guided techniques improve the visualization of operating area and also help to avoid Eustachian tube injury (Abdel-Aziz et al., 2016).

Trans-oral endoscope assisted technique has good outcomes with relatively low complication rates (Ozturk and Polat, 2012).

A prospective comparative study of 60 cases of adenoid hypertrophy for adenoidectomy were evaluated. The subjects were classified randomly into 3 groups, each of them contain 20 patients. each group were subjected to the surgery by different technique (group I by conventional curettage technique, group II by suction diathermy technique \& group III by microdebrider technique) with comparison between the different techniques as regard time of procedure, amount of bl. loss, injuries to the neighboring structures and presence of residual adenoidal tissues. As regard blood loss in our study we found high significant statistical difference between Suction diathermy technique and other two techniques.

The mean of blood loss was the lowest in suction diathermy technique (5.56 mean $\mathrm{ml}$ ) and this agree with Sethi et al. (2014) 


\section{ADENOIDECTOMY BY DIFFERENT TECHNIQUES (COMPARATIVE...}

who reported that suction diathermy afford direct vision and minimal blood loss.

Also, Reed et al. (2009) conducted same results about blood loss in suction diathermy technique (mean $4.1 \mathrm{ml}$ ).

Modayil et al. (2011) reported that monopolar suction diathermy allows controlled resection of the adenoids in a near bloodless field.

In our study, abundant blood loss was in conventional technique mean $43.45 \mathrm{ml}$ and this agree with Pandian and Shoba. (2014) which reported that mean blood loss was $42 \mathrm{ml}$.

Pandian and Shoba. 2014) and (Songu et al., 2010) explained abundant bleeding in conventional technique due to indirect vision and traumatization caused by sharp curette.

In contrast of our study, about blood loss in conventional technique, Datta et al. (2009) reported that blood loss was 21ml, and Prakash et al. (2013) was 20.9 $\mathrm{ml}$.

Prakash et al. (2013) reported as this could be due to not using too sharp adenoid curette and decreased operation time.

In our study, regarding blood loss by microdebrider technique, the mean was $31.90 \mathrm{ml}$. This agreed with Datta et al. (2009) $31.67 \mathrm{ml}$, and Prakash et al. (2013) $32.3 \mathrm{ml}$.

In our study, we found that the fastest method was conventional technique which agreed with Bradoo et al. (2011), Prakash et al. (2013) and Pandian \& Shoba. (2014).
In our study, the mean time of microdebrider was 12.8 minute. This agreed with Pandian and Shoba. (2014).

Pandian and Shoba. (2014) explained prolonged time by microdebrider as the endoscopic surgery is a bit by bit approach, the raw bleeding surface is exposed for longer time. Also increased time lead to increased amount of bleeding.

About completeness of resection of adenoid tissue microdebrider and suction diathermy, excellent results occurred in all cases .

Also, Yang et al. (2016) reported that microdebrider has superiority in completeness of removal adenoid tissue due to direct visualization and better safety.

In agreement of our study, Somani et al. (2010) found that the tissue dissection was more complete and to the appropriate depth with a microdebrider, as opposed to being too shallow or too deep with a curette.

In the preset study, we found that suction diathermy was excellent in complete of resection of adenoid tissue even choanal or tubal due to direct vision. This agreed with Sethi et al. (2014) that reported suction diathermy provides direct vision with complete resection of adenoid tissue. Also, Modayil et al. (2011) reported that monopolar suction diathermy allows controlled resection of the adenoids in a near bloodless field.

In the present study, conventional technique was associated with bad results in complete of resection which mean leaving remnants behind and this agreed with Pagella et al. (2011) which reported that the conventional adenoidectomy 
technique is criticized because the tissue to be removed cannot be visualized.

Ark et al. (2010) evaluated the use of endoscopy for the visualization of the removed adenoid tissue after the "blind curettage" was performed. The conventional technique was associated with high incidence of residual adenoid tissue. The mean percentage of residual tissue was approximately $20 \%$, especially in the peri-tubal and the choanal arch regions. These results were corroborated by (Regmi et al., 2011).

In spite of low accuracy of conventional technique is still the most basic, commonly performed, and widely available technique for adenoidectomy in many countries, even after the emergence of endoscopic techniques (Dhanasekar et al., 2010).

Conventional technique in our study revealed injury to mucosa of nasopharynx in 5 cases ( 3 to mucosa of torus and 2 cases to posterior vomer) this complications may due to blind curettage and invisibility of the field.

? ztürk and Polat. (2012) reported that the conventional technique can be inadequate. Uncontrolled and excessive resection of adenoid tissue with a sharp curette may damage prevertebral muscles. The risk of velopharyngeal insufficiency is also increased with an aggressive blind adenoidectomy.

\section{CONCLUSION}

The study demonstrated that the suction diathermy adenoidectomy is the technique of choice in lowering intraoperative blood loss compared to other tow techniques, also sharing microdebrider technique in visibility of the surgical field and completeness of resection, when the cost and availability are affordable it will be the gold standard technique for adenoidectomy, microdebrider have a disadvantages of cost and availability, the conventional technique have a disadvantages of bleeding, traumatic and incomplete of resection but still cheapest, simplest and most available one.

\section{REFERENCES}

1. Abdel-Aziz M, Khalifa B and Shawky A (2016): Trans-oral endoscopic partial adenoidectomy does not worsen the speech after cleft palate repair Braz J Otorhinolaryngol., 82(4):422-426.

2. Ark N, Kurtaran H, Ugur K Raxxell $R$ and Watson A. (2010): Comparison of adenoidectomy methods: examining with digital palpation vs. visualizing the placement of the curette. Int. J. Pediatr. Otorhinolaryngol., 74: 649-651.

3. Bradoo RA, Modi RR, Joshi AA, Pawar A and Konde S. (2011): Comparison of endoscopic assisted adenoidectomy with conventional adenoidectomy. Clinical Rhinol., 4(2):75-8.

4. Cullen KA, Hall MJ and Golosinskiy A (2009): Ambulatory surgery in the United States, Natl Health Stat Report., 1-25.

5. Datta R, Singh V and Deshpal L (2009): Conventional Versus Endoscopic Powered Adenoidectomy:A Comparative Study. MJAFI., 65:308-12.

6. Dhanasekar G, Liapi A and Turner N (2010): Adenoidectomy techniques: UK survey. J Laryngol Otol., 124: 199-203.

7. Gerhardsson H, Stalfors J, Odhagen $E$ and Sunnergren $O$ (2016): Pediatric adenoid surgery in Sweden 2004-2013: incidence, indications and concomitant surgical procedures. Int J Pediatr Otorhinolaryngol., 87:61-66.

8. Hajr E, Hagr A, Al-Arfaj A and Ashraf M (2011): Suction cautery adenoidectomy (SCA): 
is the additional cost justified? Int $\mathbf{J}$ Pediatr Otorhinolaryngol., 75:327-329.

9. Kurtaran L, Ark N, Ugur KS and Yilmaz T (2010): Comparison of adenoidectomy methods: examining with digital palpation vs. visualizing the placement of the curette, Int. J. Pediatr. Otorhinolaryngol., 74 (6) 649-651.

10. Lapińska I and Zawadzka-głos L (2016): Adenoid and tonsils hypertrophy symptoms and treatment. New Medicine, 20(4), 103-106.

11. Modayil P, Modayil G and Pai I (2011): Monopolar Suction Diathermy Adenoidectomy: Technical Note Indian J Otolaryngol Head Neck Surg: 63(1):99-100.

12. Ozturk O and Polat Ş (2012): Comparison of transoral power-assisted endoscopic adenoidectomy to curettage adenoidectomy. Advances in therapy, 1-14.

13. Pagella F, Pusateri A, Canzi $P$ and Bangad S (2011): The Evolution of the Adenoidectomy: Analysis of Different Power-Assisted Techniques. International Journal of Immunopathology and Pharmacology, 24, 5559.

14. Pandian S and Shoba $T$ (2014): Power assisted transoral endoscopic Vs conventional adenoidectomy- A comparison. Int $\mathbf{J}$ Pharm Bio Sci., 5(3):57-82.

15. Prakash N, Mallikarjunappa $A$ and Samuel H (2013): Endoscopic assisted adenoidectomy versus conventional curettage adenoidectomyA comparative study. National J Otorhinolaryngol Head \& Neck Surg., $1(10): 10-2$.

16. Reed J, Sridhara $S$ and Brietzke $S$ (2009): Electrocautery adenoidectomy outcomes: A meta-analysis. Otolaryngology - Head and Neck Surgery: 56(3): 534-344.

17. Regmi D, Mathur $\mathbf{N}$ and Bhattarai $M$ (2011): Rigid endoscopic evaluation of conventional curettage adenoidectomy. J Laryngol Otol., 125(1):53-58.
18. Ruben RJ (2017): The adenoid: its history and a cautionary tale. The Laryngoscope, 127(2): S13-S28.

19. Sethi N, Egan $P$ and Ward V (2014): Suction diathermy adenoidectomy performed in the district general hospital. Journal of Laryngology and Otology, 128(1), 78-81.

20. Somani S, Naik $C$ and Bangad $S$ (2010): Endoscopic Adenoidectomy with Microdebrider. Indian Journal of Otolaryngology and Head and Neck Surgery, 62(4): 427-431.

21. Songu M, Altay $C$ and Zehra A (2010): Endoscopic Adenoidectomy with Microdebrider versus curettage adenoidectomy: A prospective, randomized, double blind study with objective outcomes. The Laryngoscope, 120 (9): 1895-1899.

22. Wilson YL, Merer DM and Moscatello AL (2009): Comparison of three common tonsillectomy techniques: a prospective randomized, double-blinded clinical study. Laryngoscope, 119:162-170.

23. Yaman H, Memis $M$ and Ilhan $E$ (2015): Comparison of trans oral/trans nasal endoscopic-guided adenoidectomy with endoscopic nasopharyngeal inspection at the end of curettage adenoidectomy. Indian Journal of Otolaryngology and Head and Neck Surgery, 67(2), 124-127.

24. Yang L, Shan Y, Wang S Wynn $R$ and Rosenfeld M (2016): Endoscopic Assisted Adenoidectomy Versus Conventional Curettage Adenoidectomy: a Meta-Analysis of Randomized Controlled Trials, Pbl. Springer Plus, p: 5. 
استنُصال اللحمية خلف الأنف بطرق مختلفة (در اسة مقارنة) عاطف عبد الله المراغي - حاتم صلاح الدين الحبشي - حازم أحمد محمد احمد

قسم الأنف و الأذن و الحنجرةـ كلية الطب- جامعه الأزهر

خلقية البحث : تضخم اللحمية هو حالة شـائعة في الأطفال، ويمكن أن تسبب أعر اض مثل التنفس الفمي و كثرة الافر از ات الأنفيـة، و الثـخير، وتوقف النفس أثنـاء النوم، كمـا يسـاهم في التسبب في في التهابات الجيوب الأنفية والتهاب الأذن الوسطي المتكررة و التهاب الأذن الوسطي الإرنشاحي.

الهرف من البحث: المقارنة بين مختلف الأساليب الجر احية المستخدمة لاستئصسال اللحمية الخلف أنفية.

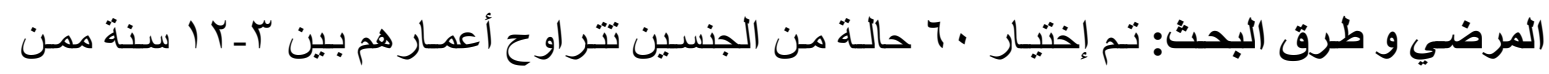
يعانون من تضخم لحمية البلعوم الأنفي والمقرر لهم إجراء عملية استنُصال اللحمية. وتم تقسيم الحالات عثو ائيا إلي ثلاثة مجمو عات متساوية:

مجمو عة (1): تم إجر اء عملية إستئصسال اللحمية بالأسلوب التقليدي والذي يعتمد علي الاحسـس بالأصبع واستخدام الكحاتة التقليدية.

مجمو عة (Y): تم إجراء الجراحة باستخدام الحالق بالإضافة للمنظار الضوئي.

مجمو عـة (ب) : تم إجر اء الجر احـة باستخدام الكي بالإنفـاذ الحراري و الثفط ، أيضـا اسـتخدام المنظار الضوئي.

وقد تم تحديد وتسجيل أوجه المقارنة بين المجمو عات الثناث و التي شملت مدة الجر احة في كل أسلوب، وكمية النزيف أثناء الجراحة ، ودرجة استكمال اللحمية ، وكذا المضاعفات التي حدثت أثناء وبعد العملية.

التتـائج: كانـت الطريقـة التقليديـة أقل الطرق التثلاث بالنسبة لوقت الجر احـة، و أكثر هـا هـي طريقـة الحالق، وقد وجد أن هذه الفروق ذات دلالـة إحصـائية عاليـة بين طريقة الحسالق و الطريقة التقليديـة، بينما لا دلالة إحصائية بين طريقة الحالق وطريقة الإنفاذ الحراري، و وكذا بالنسبة لكمبة النزيف اثناء

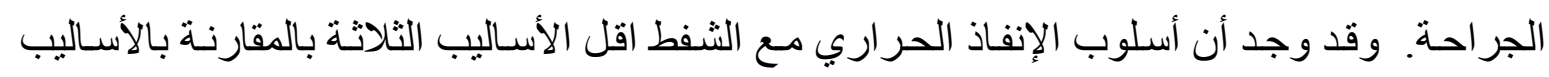
الأخرى، وهذا الفارق وجد أنه ذو دلالة إحصائية عالية. 


\section{ADENOIDECTOMY BY DIFFERENT TECHNIQUES (COMPARATIVE...}

وقد تبين من النتائج أن الطريقة التقليديـة هي أقل الطرق من حيث الاستئصـال الكامل للحميـة وكذا أكثر الأساليب الثلاثة لحدوث مضاعفات أثناء الجر احة.

الاستتتاج: أسلوب الانفاذ الحراري مع الثفط يعد أفضل الطرق الثنلاث من ناحية أنه أقل الأسـاليب في كمية النزيف أثناء الجر احة، وكذا بالمشـاركة مع طريقة الحسالق أقل الأسـاليب في حدوث مضـاعفات، وذلك لأفضلية الجر احة تحت الرؤية المباشرة للمجال الجر احي. غير أنه يعيب هذان الأسلوبين التكلفة و عدم التو افر في جميع الأمـاكن بعكس الطريقة التقليدية التي تعتبر أرخص الطرق الثناث و أسـهاها نظر ا لتو افر ها وشيو عها. 